\title{
MORPHOPHYSIOLOGY OF RHIZOBIA ISOLATED FROM NATIVE FORAGE OF FABACEAE OF THE CAATINGA ${ }^{1}$
}

\author{
SUELANE DE MELO DIAS ${ }^{2}$, ALBERÍCIO PEREIRA DE ANDRADE ${ }^{2}$, ADAILSON PEREIRA DE SOUZA $^{3}$, ANDRÉ \\ LUIZ RODRIGUES MAGALHÃES ${ }^{2}$, RISELANE DE LUCENA ALCÂNTARA BRUNO ${ }^{3}$, ROBERTA DE LIMA \\ VALENÇA ${ }^{2 *}$
}

\begin{abstract}
The rhizobia found in Fabaceae plants of the Caatinga may have potential as fodder in the semiarid region, thus increasing the availability of feed for animal production in this region. This study aimed to characterize the morphophysiology of rhizobia strains of the forage species Mimosa tenuiflora (Jurema preta), Macroptilium atropurpureum (Siratro), and Desmanthus pernambucanus (Jureminha). The soil used as the substrate was collected at specific locations in the municipalities of Sertânia, Arcoverde, and São Bento do Una, state of Pernambuco. The characterization of rhizobial colonies included growth period, diameter, elevation, transparency, exopolysaccharides production, and color. In addition, salinity, temperature, and $\mathrm{pH}$ tolerance tests of the native rhizobia were conducted. Evaluation of cultures showed that the isolates formed colonies with flat elevation, moderate production of exopolysaccharides, coloration varying from cream to white, and a smooth surface. Physiological tests of abiotic stress resistance showed that the native species isolated from $M$. tenuiflora were more resistant when grown in soils from the municipality of Sertânia and isolates from $M$. atropurpureum and D. pernambucanus had high resistance to high temperatures, regardless of place of farming. It can be concluded that native rhizobia from the Semiarid region of Pernambuco show resistance to stress caused by high temperatures, salinity variation, and $\mathrm{pH}$. These characteristics are influenced by soil and the botanical species in symbiosis with the rhizobia.
\end{abstract}

Keywords: Mimosa tenuiflora. Macroptilium atropurpureum. Desmanthus pernambucanus. Diazotrophic microorganisms. Nitrogen.

\section{MORFOFISIOLOGIA DE RIZÓBIOS ISOLADOS EM FABÁCEAS FORRAGEIRAS NATIVAS DA CAATINGA}

\begin{abstract}
RESUMO - Os rizóbios encontrados em fabáceas da Caatinga podem ser uma via para o cultivo de forragens no Semiárido, possibilitando, assim, aumentar a disponibilidade de alimento para a produção animal nesta região. Objetivou-se caracterizar morfofisiologicamente estirpes de rizóbios nativos das espécies forrageiras, Mimosa tenuiflora, (Jurema preta), Macroptilium atropurpureum (Siratro) e Desmanthus pernambucanus (Jureminha). O solo usado como substrato foi coletado em pontos específicos dos municípios de Sertânia, Arcoverde e São Bento do Una, estado de Pernambuco. A caracterização das colônias de rizóbios foi feita quanto ao tempo de crescimento, diâmetro, elevação, transparência, produção de exopolissacarídeos e coloração. Também foram feitos testes de tolerância dos rizóbios nativos em diferentes níveis de salinidade, temperatura e pH. Na avaliação cultural observou-se que os isolados formaram colônias com elevação plana, moderada produção de exopolissacarídeos, coloração variando de creme a branca e superfície lisa de acordo com cada isolado. Os testes fisiológicos de resistência a estresses abióticos mostraram que os isolados nativos de Mimosa tenuiflora foram mais resistentes quando cultivados nos solos provenientes do município de Sertânia, enquanto os isolados de $M$. atropurpureum e $D$. pernambucanus tiveram elevada resistência a altas temperaturas, independente do local de cultivo. Conclui-se que os rizóbios nativos da região Semiárida de Pernambuco apresentam resistência ao estresse causado por altas temperaturas, variação na salinidade e $\mathrm{pH}$. Essas características são influenciadas pelo solo e espécie botânica em simbiose com os rizóbios.
\end{abstract}

Palavras-chave: Mimosa tenuiflora. Macroptilium atropurpureum. Desmanthus pernambucanus. Microrganismos diazotróficos. Nitrogênio.

\footnotetext{
*Corresponding author

${ }^{1}$ Received for publication in $02 / 19 / 2019$; accepted in 09/12/2019.

Paper extracted from the master's dissertation of the first author.

${ }^{2}$ Departament of Animal Production, Universidade Federal Rural de Pernambuco, Garanhuns, PE, Brazil; suelane.md@gmail.com ORCID: 0000-0002-3316-340X, albericio3@gmail.com - ORCID: 0000-0002-1223-394X, andre30036@gmail.com - ORCID: 0000-0003 -2211-6795, robertalimav@hotmail.com - ORCID: 0000-0003-1341-1602.

${ }^{3}$ Center of Agrarian Sciences, Universidade Federal da Paraíba, Areia, PB, Brazil; adailson.ufpb@yahoo.com.br - ORCID: 0000-00032049-6069, lanebruno.bruno@gmail.com - ORCID: 0000-0002-4206-6417.
} 


\section{INTRODUCTION}

The cultivation of plants with high protein content and with forage potential is considered a viable alternative for maximizing animal production and contributing to the increase in soil organic matter input. Fabaceae species introduced in semiarid climate regions are generally cultivated for the purpose of green manure, in symbiosis with diazotrophic microorganisms that contribute significantly to the improvement of soil chemical, physical, and biological characteristics (CARVALHO; PIRES, 2008). However, the main limiting factor in the production of these Fabaceae plants is their low resistance to the environmental conditions of Semiarid regions. In contrast, several native species of the Semiarid region are conspicuous for their resilience to the climatic factors of the region, possessing a high protein level in their composition besides providing products of high commercial value, such as wood (SANTOS; SANTOS, 2011).

Certain characteristics of soils in regions under semiarid climate, such as acidity and salinity, strongly affect the yield of Fabaceae plants. This problem can be minimized by symbiosis with native diazotrophic bacteria, ensuring greater production capacity of these plants by increasing the nitrogen fixed by rhizobia (LARANJO; ALEXANDRE; OLIVEIRA, 2014). Biological nitrogen fixation is mediated by a diverse group of prokaryotic microorganisms with broad morphophysiological, genetic, biochemical, and phylogenetic characteristics. This biodiversity ensures ecosystem stability and resilience as it is linked to the processes of soil formation, nutrient cycling, and nutrient storage (MOREIRA et al., 2010).

Housed in root nodules, the rhizobia make nitrogen available to plants in exchange for carbohydrates produced through photosynthesis, also making use of other mechanisms such as stimulating plant growth, including other families. Other prominent mechanisms include the production of plant hormones, (mainly auxins which increase growth of the root system and consequently the ability to absorb nutrients), phosphate solubilization, and plant protection against phytopathogenic fungal attacks (DUTTA et al, 2008, YANNI; DAZZO, 2010).

The objective of this study was to characterize the morphophysiology of rhizobial strains of the native forage species Mimosa tenuiflora (Willd) Poiret, Macroptilium atropurpureum (OC.) Urb., e and Desmanthus pernambucanus (L.) Thellung, cultivated in soils from the Caatinga areas of the municipalities of Sertânia, Arcoverde, and São Bento do Una in the state of Pernambuco, Brazil.

\section{MATERIAL AND METHODS}

The experiment was performed in a screened greenhouse belonging to the Seed Analysis Laboratory of the Universidade Federal da Paraíba, for five months with the plant species Mimosa tenuiflora, Macroptilium atropurpureum, Desmanthus pernambucanus. Soil samples were collected at a depth of 0-20 cm in January 2014, in the municipality of São Bento do Una, site Fazenda Nova, located in the mesoregion of the Southern Agreste, a homogeneous microregion of the Vale do Ipojuca, with Caatinga vegetation presenting anthropization characteristics, such as selective and aggressive cutting of tree and shrub species with flammable potential. The Caatinga is a Brazilian biome that has a semiarid climate and is endowed with a deciduous forest. In the municipality of Sertânia, the soil collection took place at the Estação Experimental de Pernambuco (IPA), located in the Moxotó microregion and the Sertão mesoregion. In the municipality of Arcoverde the collections were performed in a region with a well preserved Caatinga vegetation, characterized as Caatinga de Cipó, although there is strong evidence of anthropization such as the demarcation of areas with fences and clearings along the vegetation. All municipalities are located in the state of Pernambuco, Brazil (Table 1).

Table 1. Georeferenced soil collection locations in the municipalities of Sertânia, Arcoverde, and São Bento do Una, Pernambuco, Brazil.

\begin{tabular}{|c|c|c|c|}
\hline \multirow[b]{2}{*}{ Area } & \multicolumn{3}{|c|}{ Municipality } \\
\hline & Sertânia & Arcoverde & São Bento do Una \\
\hline \multirow[t]{2}{*}{1} & $37^{\circ} 13^{\prime} 08.7^{\prime \prime} \mathrm{W}$ & $37^{\circ} 00 ' 34.3 " \mathrm{~W}$ & $36^{\circ} 31^{\prime} 16.8^{\prime \prime} \mathrm{W}$ \\
\hline & $08^{\circ} 02 ’ 31,2 ” \mathrm{~S}$ & $08^{\circ} 25^{\prime} 59.3^{\prime \prime} \mathrm{S}$ & $08^{\circ} 32 ’ 14,8 ’ \mathrm{~S}$ \\
\hline 2 & $08^{\circ} 03 ’ 52.3 ” \mathrm{~S}$ & $08^{\circ} 25^{\prime} 54.8^{\prime \prime} \mathrm{S}$ & $08^{\circ} 32^{\prime} 15,5^{\prime \prime} \mathrm{S}$ \\
\hline 3 & $37^{\circ} 13^{\prime} 39.8^{\prime \prime} \mathrm{W}$ & $37^{\circ} 00^{\prime} 28.4^{\prime \prime} \mathrm{W}$ & $36^{\circ} 31^{\prime} 16.2^{\prime \prime} \mathrm{W}$ \\
\hline
\end{tabular}


The procedure of soil collection for the cultivation of Fabaceae plants was as follows. Three distinct points were randomly chosen in each area equidistant at least $10 \mathrm{~m}$ from each other. At each point, a circumference with a radius of approximately $1 \mathrm{~m}$ around a Fabaceae plant found at the site (M. tenuiflora) was marked with a pickaxe.
The rhizospheric soil was removed at a depth of 0 $20 \mathrm{~cm}$. After collection, the soils were transported to the laboratory in thermal boxes, broken, homogenized, and sieved with $2.0 \mathrm{~mm}$ mesh. A subsample of soil was reserved for the determination of physical and chemical characteristics (Table 2).

Table 2. Physical and chemical characteristics of the soil of the municipalities of Sertânia, Arcoverde, and São Bento do Una, Pernambuco, Brazil.

\begin{tabular}{|c|c|c|c|}
\hline & \multicolumn{3}{|c|}{ Municipality } \\
\hline & Sertânia & Arcoverde & São B. do Una \\
\hline \multicolumn{4}{|l|}{ Physical Characteristics } \\
\hline \multicolumn{4}{|l|}{ Sand } \\
\hline Coarse $(2-0.2 \mathrm{~mm})$ & 404 & 458 & 379 \\
\hline Fine $(0.2-0.05 \mathrm{~mm})$ & 255 & 197 & 283 \\
\hline Silt $(0.05-0.002 \mathrm{~mm})$ & 223 & 199 & 255 \\
\hline Clay $(<0.002 \mathrm{~mm})$ & 118 & 146 & 113 \\
\hline Textural Class & Sandy loam & Sandy loam & Sandy loam \\
\hline \multicolumn{4}{|l|}{ Chemical Characteristics } \\
\hline $\mathrm{pH} \mathrm{H}_{2} \mathrm{O}(1: 2.5)$ & 6.93 & 5.8 & 5.44 \\
\hline$P\left(\mathrm{mg} \mathrm{dm}^{-3}\right)$ & 28.5 & 16.3 & 27.1 \\
\hline $\mathrm{K}^{+}\left(\mathrm{cmol}_{\mathrm{c}} \mathrm{dm}^{-3}\right)$ & 234 & 209 & 193 \\
\hline $\mathrm{Na}^{+}\left(\mathrm{cmol}_{\mathrm{c}} \mathrm{dm}^{-3}\right)$ & 0.06 & 0.04 & 0.06 \\
\hline $\mathrm{Ca}^{+2}\left(\mathrm{cmol}_{\mathrm{c}} \mathrm{dm}^{-3}\right)$ & 7.1 & 2.5 & 3.05 \\
\hline $\mathrm{Mg}^{+2}\left(\mathrm{cmol}_{\mathrm{c}} \mathrm{dm}^{-3}\right)$ & 1.0 & 1.25 & 1.15 \\
\hline $\mathrm{Al}^{+3}\left(\mathrm{cmol}_{\mathrm{c}} \mathrm{dm}^{-3}\right)$ & 0.0 & 0.0 & 0.05 \\
\hline $\mathrm{H}^{++} \mathrm{Al}^{+3}\left(\mathrm{cmol}_{\mathrm{c}} \mathrm{dm}^{-3}\right)$ & 0.16 & 1.15 & 1.15 \\
\hline $\mathrm{SB}\left(\mathrm{cmol}_{\mathrm{c}} \mathrm{dm}^{-3}\right)$ & 8.76 & 4.33 & 4.75 \\
\hline $\mathrm{CEC}\left(\mathrm{cmol}_{\mathrm{c}} \mathrm{dm}^{-3}\right)$ & 8.92 & 5.48 & 5.91 \\
\hline $\mathrm{V} \%$ & 98.2 & 78.9 & 80.5 \\
\hline $\mathrm{m} \%$ & 0 & 0 & 1.01 \\
\hline $\mathrm{OM}\left(\mathrm{g} \mathrm{dm}^{-3}\right)$ & 26.36 & 19.11 & 18.17 \\
\hline
\end{tabular}

$\mathrm{H}+\mathrm{Al}=$ potential acidity; $\mathrm{SB}=$ sum of bases; $\mathrm{CEC}=$ cation exchange capacity; $\mathrm{V}=$ base saturation; $\mathrm{m}=$ aluminum saturation; $\mathrm{OM}=$ organic matter.

Pots with a capacity of $2 \mathrm{~kg}$ and $1 \mathrm{~kg}$ were used for trees and shrubs and herbaceous plants, respectively. Before planting the Fabaceae species, dormancy was broken by soaking the seeds in hot water (between 80 and $90{ }^{\circ} \mathrm{C}$ ) for $30 \mathrm{~s}$ and subsequently in water at room temperature $\left(25^{\circ} \mathrm{C}\right)$ for 1 min (BAKKE et al., 2006).

Three seeds were sown per pot, 9 pots per legume, totaling 81 pots. After seedling emergence, thinning was performed, and only two plants were 
used to obtain root nodules, approximately 45 days after planting of herbaceous plants, 65 days for shrubs, and 90 days for trees. At the end of the experiment, the roots were collected and washed using a $2.0 \mathrm{~mm}$ sieve. The roots with the nodules were dried on paper towels and broken into smaller pieces. After this cleaning, 10-15 root nodules were selected per plant and preserved in hermetically sealed containers containing cotton and pearly silica.

For the morphophysiology laboratory tests, six nodules from each replicate were randomly selected, totaling 162 isolates for each species. The disinfection of nodules followed the methodology proposed by Hungria and Araújo (1994), which comprises treatment of the nodules with $70 \%$ ethyl alcohol solution for $1 \mathrm{~min}$ to break the surface tension and with a $1 \%$ sodium hypochlorite solution for $2 \mathrm{~min}$ for surface disinfection, then washed five times with sterile distilled water, to remove excess hypochlorite. Subsequently, the nodules were macerated with a sterile glass rod and then inoculated in culture medium of yeast-mannitol agar (YMA) (VINCENT, 1970) with the addition of 5.0 $\mathrm{mL} \mathrm{L}{ }^{-1}$ Congo red as described by Fred and Waksman (1928).

The sampled material was incubated in a BOD (Biological Oxygen Demand) chamber at $28^{\circ}$ $\mathrm{C}$ for 10 days. After the incubation period, bacterial growth was measured according to the method described by Melloni et al. (2006). The morphological characteristics of the colonies were determined along with the growth period. After three days of incubation, the diameter (in millimeters) of the colonies was measured with the aid of a colony counter.

Shape was determined as punctiform, smooth, or irregular. The elevation was considered flat, dome -shaped, or conical. The coloration was classified as yellow, cream, colorless, white, or pink. Cream, white, or colorless indicates that the bacteria do not change the $\mathrm{pH}$ of the medium, while the yellow and pink color indicate modification. The surface of the colony was classified as smooth, rough, or papillate. Exopolysaccharide production was visually determined as sparse, poor, moderate, and abundant (MELLONI et al., 2006).

For physiological characterization of $\mathrm{pH}$ modification by colorimetric aspect, rhizobial isolates were inoculated in modified YMA medium with the addition of $10 \mathrm{~mL} \mathrm{~L}^{-1}$ of bromothymol blue (VINCENT, 1970). The acidifying rhizobial isolates turn the medium yellow, the alkalinizing isolates turn the green medium bluish, and the neutral ones do not change the color of the culture medium ranging from beige, white, and transparent.

The growth capacity of rhizobia at different temperatures was determined by inoculating bacteria into test tubes containing $5.0 \mathrm{~mL}$ YMA (VINCENT, 1970) and incubating at 28, 35, and 40 ${ }^{\circ} \mathrm{C}$ for 10 days. Tubes that presented turbidity in the sample, were considered positive and those that did not present turbidity in the sample as negative. A treatment without inoculation was used as the reference.

To evaluate the growth capacity at different $\mathrm{pH}$, test tubes containing $5.0 \mathrm{~mL}$ YMA with $\mathrm{pH}$ values of $4,5,6,7$, and 8 , adjusted using $1 \mathrm{~mol} \mathrm{~L}^{-1}$ $\mathrm{NaOH}$ and $\mathrm{HCl}$, were inoculated and incubated at room temperature under $120 \mathrm{rpm}$ agitation. Growth analysis was determined after three days of incubation.

The ability to grow at different salt concentrations was determined by incubating the isolates in test tubes containing $5 \mathrm{~mL}$ YMA (VINCENT, 1970) with $0.1,0.5,1,5$, and $10 \%$ of culture-soluble $\mathrm{NaCl}$ corresponding to $0.27,1.35$, $2.70,13.5$, and $27 \mathrm{~g} \mathrm{~L}^{-1}$, respectively, at room temperature with shaking at $120 \mathrm{rpm}$ for three days. As soil salinity is expressed as electrical conductivity of the saturation extract (ECse) (SILVA et al., 2013), the ECse in $\mathrm{dS} \mathrm{m}^{-1}$ of each $\mathrm{NaCl}$ concentration in liquid YMA medium was determined (Table 3).

Table 3. Electrical conductivity of YM (Yeast Mannitol) medium equivalent to $\mathrm{NaCl}$ levels in YM solution.

\begin{tabular}{cc}
\hline Level of $\mathrm{NaCl} \mathrm{g} \mathrm{L}^{-1}$ & Electrical Conductivity $\left(\mathrm{dS} \mathrm{m}^{-1}\right)$ \\
\hline 0.27 & 2.77 \\
1.35 & 8.32 \\
2.7 & 16.76 \\
13.5 & 64.70 \\
27.0 & 103.8 \\
\hline
\end{tabular}

\section{RESULTS AND DISCUSSION}

The nodules of the three Fabaceae plants under study presented, in general, particular forms inherent to each species; a dark red interior which is supposed to be because of the presence of leghemoglobin. According to Vorster et al. (2013), one of the main roles of leghemoglobin is to control 
oxygen intake in the nodule, because the nitrogenase enzyme present in the bacterioid is highly sensitive and can be inactivated when in contact with large amounts of this gas. According to the authors, the decrease in biological nitrogen fixation is associated with a reduction in the ability of leghemoglobin to control oxygen entry.
The nodulation potential (Table 4) of the species $M$. tenuiflora was considered satisfactory. One hundred percent of the evaluated plants nodulated, regardless of the soil in which they were grown. According to Araujo et al. (2010), M. tenuiflora is a widely occurring Fabaceae plant in the north-eastern Brazilian states found in the Caatinga vegetation and presents low symbiotic specificity.

Table 4. Nodulation index of isolates of three Fabaceae forage species from the Semiarid Caatinga.

\begin{tabular}{lccc}
\hline \multirow{2}{*}{ Study Region } & \multicolumn{3}{c}{ Nodulation (\%) } \\
\cline { 2 - 4 } & Mimosa tenuiflora & Macroptilium atropurpureum & Desmanthus pernambucanus \\
\hline Sertânia & 100 & 100 & 77.7 \\
Arcoverde & 100 & 100 & 37 \\
São Bento do Una & 100 & 92.5 & 11 \\
\hline
\end{tabular}

The species with the second highest nodulation index was $M$. atropurpureum, which reached $100 \%$ nodulation in soils from the Sertânia and Arcoverde locations, with a small decrease when cultivated in the soil from the sampling areas of the municipality of São Bento do Una (92.5\%). D. pernambucanus showed greater difficulty in nodulation by native rhizobial strains from the soils of Sertânia, Arcoverde, and São Bento do Una, with natural occurrence of rhizobia only in $77.7 ; 37$, and $11 \%$, respectively, of the samples of the plants analyzed.

According to Teixeira et al. (2010), the symbiosis process can be influenced by the chemical composition of different exudates released into the rhizosphere by the roots of the plants, as well as by the soil use system. Because of the symbiotic relationship with Fabaceae, it is suggested that the diversity of rhizobia is closely related to the variety of nodular species at the site, implying evolutionary adaptations of both symbionts.

All isolates obtained grew from two to three days, being characterized as fast-growing bacteria (Figure 1A, B, C). According to Medeiros et al. (2009), rapidly growing noduliferous bacteria are commonly found in the Semiarid regions. This characteristic is one of the mechanisms of survival of these microorganisms, because the tolerance to semiarid environments is owing to the rapid multiplication in a short period, thus, reducing the time between generations, which would explain their higher frequency in these soils in relation to bacteria of slow growth.

Freitas et al. (2007) characterized isolates of jacatupé rhizobia (Pachyrhizus tuberosus) cultivated in saline soil of the state of Pernambuco, and observed that all isolates had rapid growth and also attributed this characteristic to soil properties. Thus, the growth period seems to be associated with environmental conditions such as water availability, temperature, $\mathrm{pH}$, and soil fertility.

Souto et al. (2008), evaluating microorganism populations and edaphic mesofauna in the semiarid region of Paraiba, verified a reduction in the bacterial population from December to February and from May to July; this reduction in the bacterial population was probably related to the effects caused by water stress.

The isolates of native rhizobia from the municipality of São Bento do Una had a moderate production of exopolysaccharides regardless of the botanical species under study. However, the native isolates of the municipality of Sertânia and Arcoverde had different behaviors; this variation can be attributed to the type of plant cultivated, and the symbiosis formed in the rhizobium-Fabaceae interaction.

The colony size is directly associated with the production of exopolysaccharides (Figure 1A, B, C), because colonies larger than $2.0 \mathrm{~mm}$ usually presented moderate and abundant exopolysaccharide production. According to Monteiro et al. (2012), genera of diazotrophic bacteria of the Rhizobiaceae family produce considerable amounts of exopolysaccharides that are used for fixation to roots of Fabaceae plants in processes that facilitate nutrient collection, protection against environmental stress, and host defenses.

Higher production of exopolysaccharides by bacterioids from São Bento do Una can be explained by soil conditions, since the area presented higher active acidity. According to Oliveira et al. (2014), exopolysaccharides are biologically designed to protect microbial cells from environmental stresses such as desiccation, osmotic stress, antibiotics, toxic compounds, and increase the absorption capacity of water and nutrients.

Extracellular polymeric substances of which 
polysaccharides are a part can be combined with greater pore scale soil water retention. Deng et al. (2015) demonstrated this while evaluating the synergistic effects of bacterial extracellular polymeric substances on the drying rate of soil microstructure. Hussain et al. (2014), studying the effect of catalase and exopolysaccharides produced by rhizobia under water stress in wheat, showed that the effect of these two components in Rhizobium and Mesorhizobium species had a beneficial influence in wheat, a non-Fabaceae species, under water stress. In addition, the ability of rhizobia to produce catalase and exopolysaccharides is not only a property of water stress tolerance, but also a reliable attribute for selecting efficient rhizobia for the improvement of non-Fabaceae plant yields.

Most colonies formed were circular in shape. The characteristic of irregular colonies were observed mainly in relation to the species of $M$. tenuiflora and $M$. atropurpureum when cultivated in the soil coming from São Bento de Una, considering that this was the place of cultivation that provided the largest number of isolates with greater abundance of exopolysaccharides.

The surface of the colony is another feature that is directly related to the production of exopolysaccharides, because when there is abundant production of these compounds the colony tends to be smooth. However, when there is a shortage of exopolysaccharides, the surface of the colony appears to have lumps and is termed as rough (SANTOS et al., 2007). The characteristic of smooth surface and flat elevation of the colonies predominated in all isolates cultivated in soils of the three evaluated municipalities.

It was also observed that most $D$. pernambucanus isolates form flat elevation colonies when grown in the soil from the municipalities of Sertânia and Arcoverde; however, in the soil of the municipality of São Bento do Una, $66.7 \%$ of the colonies were dome-shaped and only $33.3 \%$ had a flat elevation. The conical shape of the colonies appeared only in some isolates of $M$. atropurpureum and $D$. pernambucanus species. The coloration of the colonies ranged from cream, white, colorless, and yellow. The cream color of the colonies was more frequently observed in the species $M$. tenuiflora and $M$. atropurpureum with higher occurrence in soils from the municipalities of Arcoverde and Sertânia, respectively.

The species D. pernambucanus was predominantly white when cultivated in soils from the municipalities of Sertânia (73\%), Arcoverde
$(80 \%)$, and São Bento do Una $(83.3 \%)$. The highest number of colorless colonies (30\%) was observed in M. atropurpureum when cultivated in soil from São Bento do Una. The yellow color was observed in only $9.3 \%$ of the $M$. atropurpureum colonies cultivated in the soil of the municipality of Arcoverde.

These data reflect the influence of the botanical species on the color of the colonies and it was observed that the soil has little or no influence on this trait. Most colonies were classified as neutral, that is, they did not modify the $\mathrm{pH}$ of the medium; only a small percentage of rhizobia of the species $M$. tenuiflora and $M$. atropurpureum acidified the medium in all studied soils.

The isolates of native rhizobia from $M$. tenuiflora, $M$. atropurpureum, and $D$. pernambucanus showed high tolerance to stress conditions caused by high temperatures, different salinity levels, and $\mathrm{pH}$ (Figure 2A, B, C). There was $100 \%$ bacterial growth at different $\mathrm{pH}$ of isolates obtained from $M$. tenuiflora cultivated in the soil from the municipality of Sertânia. The second highest degree of resistance to $\mathrm{pH}$ differences was observed in soil from Arcoverde, with $100 \%$ growth only at $\mathrm{pH} 6$ and 7 and $85.2 \%$ growth of the isolates at the other $\mathrm{pH}$ values. $M$. tenuiflora isolates, when grown in São Bento do Una soil, did not grow when subjected to $\mathrm{pH} \mathrm{4}$, and it was possible to observe growth from $\mathrm{pH} 5$, with maximum bacterial growth at $\mathrm{pH} 7$, taking into account that $\mathrm{pH} 7$ is considered ideal for microbial growth (BHATTACHARYA; DESHPANDE; PANDEY, 2013).

The highest growth value of $M$. atropurpureum native isolates was $86.1 \%$ in the $\mathrm{pH}$ 4 culture medium and the lowest value of $47.2 \%$ in the $\mathrm{pH} 8$ culture medium. In the soil of Arcoverde, 83.3 and $81.5 \%$ growth at $\mathrm{pH} 5$ and 7 , respectively, was prominent. Bacterial growth at different $\mathrm{pH}$ showed decreasing values, but with higher values, with $100 \%$ growth in the culture medium with $\mathrm{pH} 4$ and $80 \%$ growth for $\mathrm{pH} 8$.

Native rhizobia isolates of $D$. pernambucanus cultivated in the soil of the municipality of Sertânia showed the lowest growth values compared to the other species in all evaluated regions, with a maximum growth of $61.9 \%$ and minimum of $19 \%$ for $\mathrm{pH} 6$ and 4, respectively. The bacteria isolated from $D$. pernambucanus grown in soil from

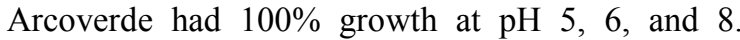
Bacterial growth at different $\mathrm{pH}$ seems to have been influenced by the botanical species in symbiosis and their cultivation soil. 
A

Sertânia

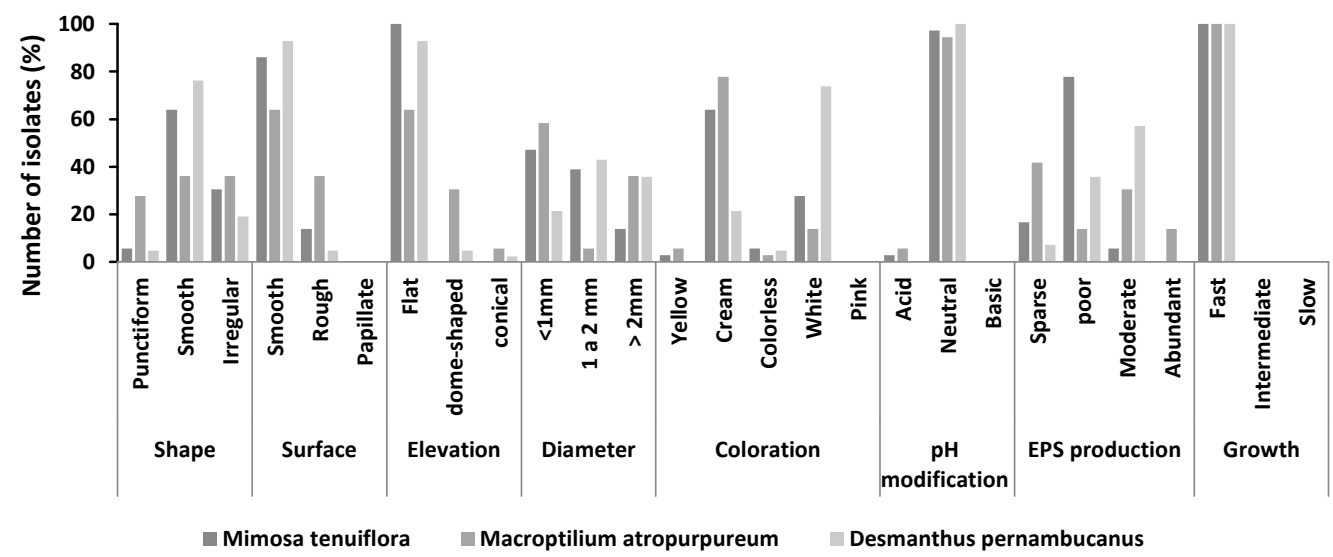

B

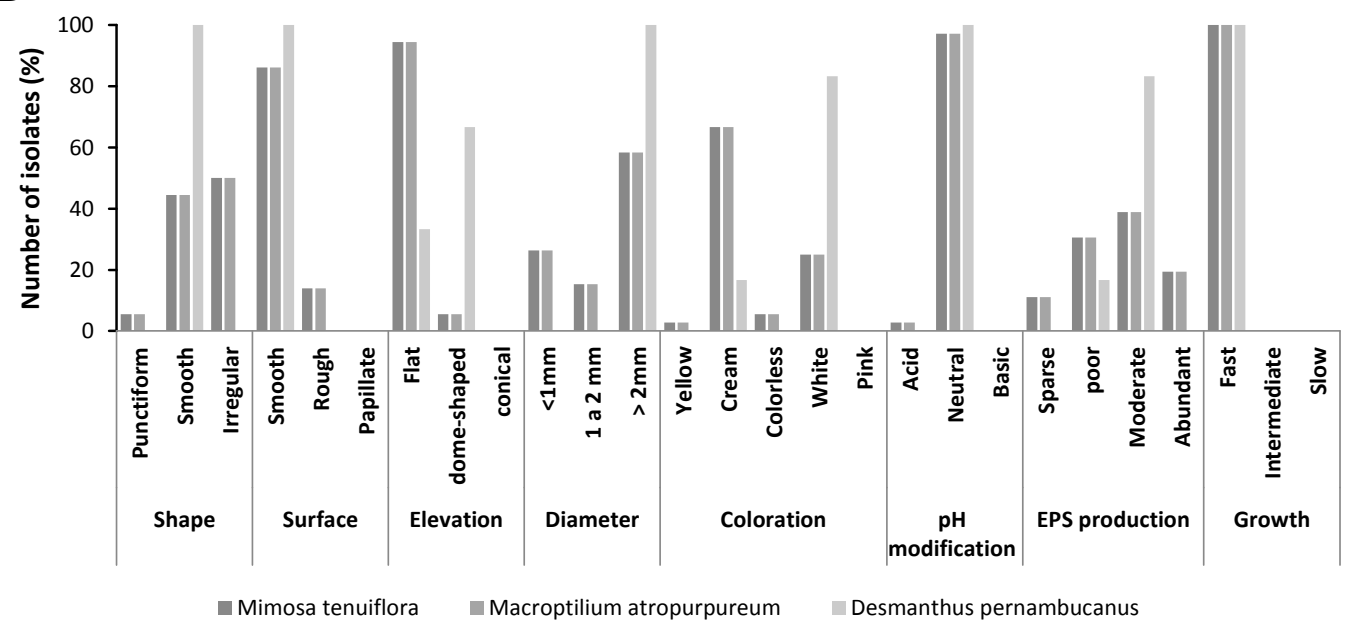

Arcoverde

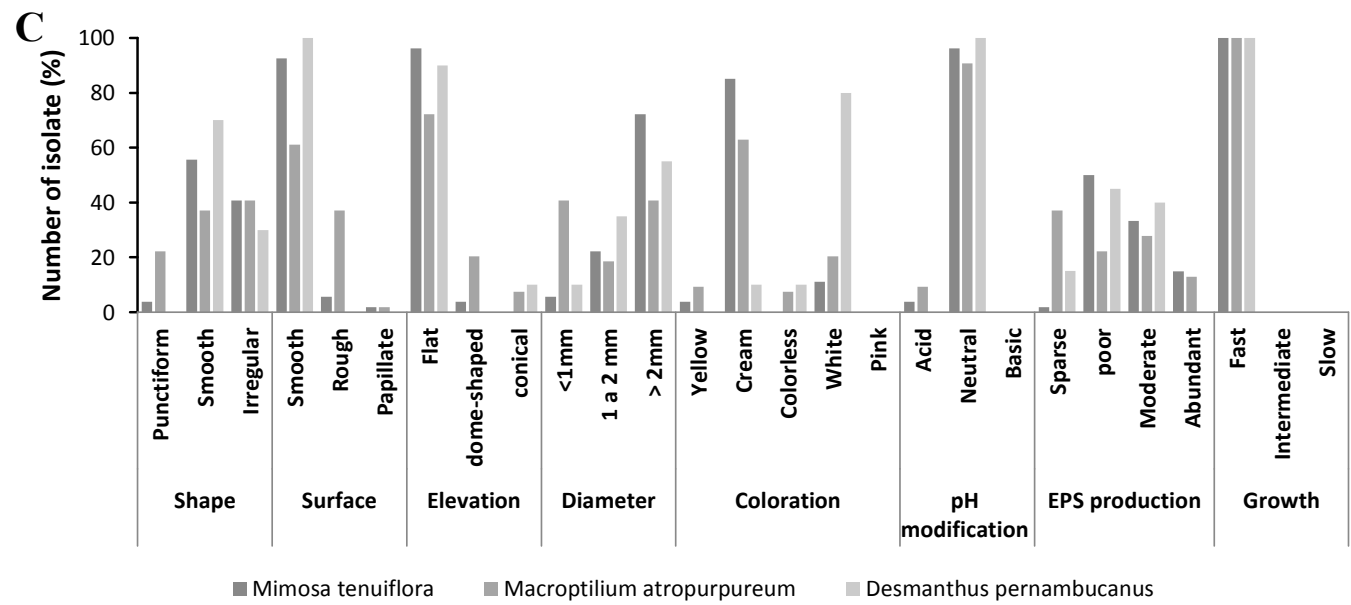

Figure 1. Colonization characteristics of rhizobia isolates in yeast-mannitol agar (YMA) medium from Mimosa tenuiflora, Macroptilium atropurpureum, and Desmanthus pernambucanus cultivated in soils of specific locations of the municipalities of (A) Sertânia, (B) Arcoverde, and (C) São Bento do Una, Pernambuco, Brazil. EPS = Extracellular polymeric substances. 
The adaptation to low $\mathrm{pH}$ is apparently triggered in most bacteria by genes such as actA, actP, Exor, lpia, ActR, and phrR that result in acidic protection inducing increased resistance to so-called acid shocks (DAKORA, 2012), with the consequent survival of rhizobia at low $\mathrm{pH}$. According to AbdAlla et al. (2014), the actA gene encodes factors responsible for maintaining internal $\mathrm{pH}$ at 7 , when outer $\mathrm{pH}$ is below 6 . They reported that microorganisms defective in this gene are unable to maintain intracellular $\mathrm{pH}$ and cannot grow at $\mathrm{pH}$ less than 6 .

Another series of acid shock gene-inducible strategies may contribute to the resilience process of rhizobia such as intracellular accumulation of low molecular weight organic solutes, alkalinization of the external environment, changes in cell envelope composition, production of chaperone proteins, expression of transcriptional regulators, and responses to changes in cell density. However, the mechanisms of response to an acid shock are not identical between rhizobia species and may or may not be responsible for the tolerance of the strain to acid conditions (LARANJO; ALEXANDRE; OLIVEIRA, 2014).

Alkalinity is less detrimental to rhizobia survival (LEBRAZI; BENBRAHIM, 2014); however, it can be a problem depending on the tolerance level of the strain. In soils with alkaline $\mathrm{pH}$, nutrient availability is reduced, and this type of stress can slow rhizobia growth, inhibit symbiosis, and subsequent nitrogen fixation (ABD-ALLA et al., 2014).

Soil salinity affects almost $40 \%$ of the world's land surface and is one of the abiotic factors that must be taken into account because it is detrimental to agriculture mainly in arid and semi-arid zones (LEBRAZI ; BENBRAHIM, 2014). Damage caused by the misuse of natural resources directly affects the soil and can trigger processes such as salinization of large areas, reducing the survival and growth of rhizobia in the soil, and inhibiting the symbiosis between micro and macrosymbionts resulting in lower productivity of these plants (LARANJO; OLIVEIRA, 2011)

Salinity tolerance tests of rhizobia resulted in decreased growth as salt concentration increased in culture medium (Figure 2A, B, C). The isolates of native $M$. tenuiflora rhizobia were more resistant when cultivated in the soils of Sertânia. However, from the salinity level of $1 \%$ there was a decrease in the growth of isolates. In the other soils, there was a reduction in growth from the $0.1 \%$ salinity level. The M. atropurpureum isolates, when cultivated in soils from Arcoverde and São Bento do Una, presented higher salt resistance when treated with the highest $\mathrm{NaCl}$ concentration (10\%), with 64.1 and $80 \%$ growth, respectively. The isolates of native rhizobia from the Arcoverde and São Bento do Una regions of the D. pernambucanus species showed higher resistance to salinity.

Some strains of rhizobia showed higher growth at $0.5 \%$ saline concentration, while at lower salt concentrations $(0.1 \%)$ the growth of rhizobia was reduced. These strains of rhizobia can be considered moderately halophytic according to Laranjo and Oliveira (2011), who observed similar growth in Mesorhizobium bacteria grown in different saline concentrations.

The same authors report that strains subjected to saline stress had a qualitative and quantitative increase in proteins with high molecular weight. This production may be related to the resilience of bacteria to stress, as they were only produced after being subjected to abnormal conditions. The accumulation of compatible intracellular solutes and stiffening of the cell wall is one of the salinity response mechanisms caused by $\mathrm{NaCl}$.

According to Vriezen, Bruijn and Nusslein (2007), the compatible osmoprotectants and solutes such as carbohydrates and disaccharides may also increase survival during desiccation caused by saline environments. The evaluation of bacterial growth potential at different temperatures showed a decreasing trend with the increase in temperature for M. tenuiflora in soils of all sites evaluated. Rhizobia found in nodules collected in M. tenuiflora showed growth of around 97.7 to $100 \%$ at $28{ }^{\circ} \mathrm{C}$, considered ideal for rhizobia development and survival (GOMES et al., 2012). At $40{ }^{\circ} \mathrm{C}$, growth reached 77.7, 63.0, and $38.9 \%$ in the soils of Sertânia, Arcoverde, and São Bento do Una, respectively. In native isolates of $M$. atropurpureum, a higher tolerance to temperature variation was observed in relation to the other species, with about $90 \%$ bacterial growth at $40{ }^{\circ} \mathrm{C}$. 
A

Sertânia

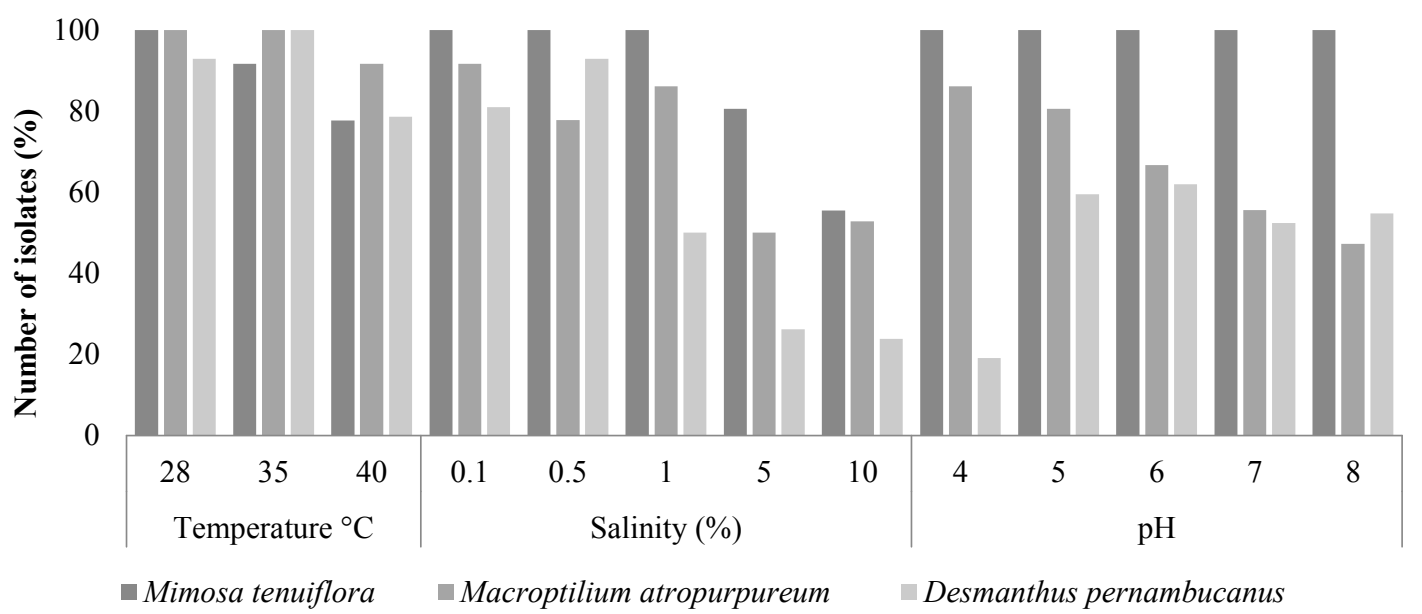

B

Arcoverde

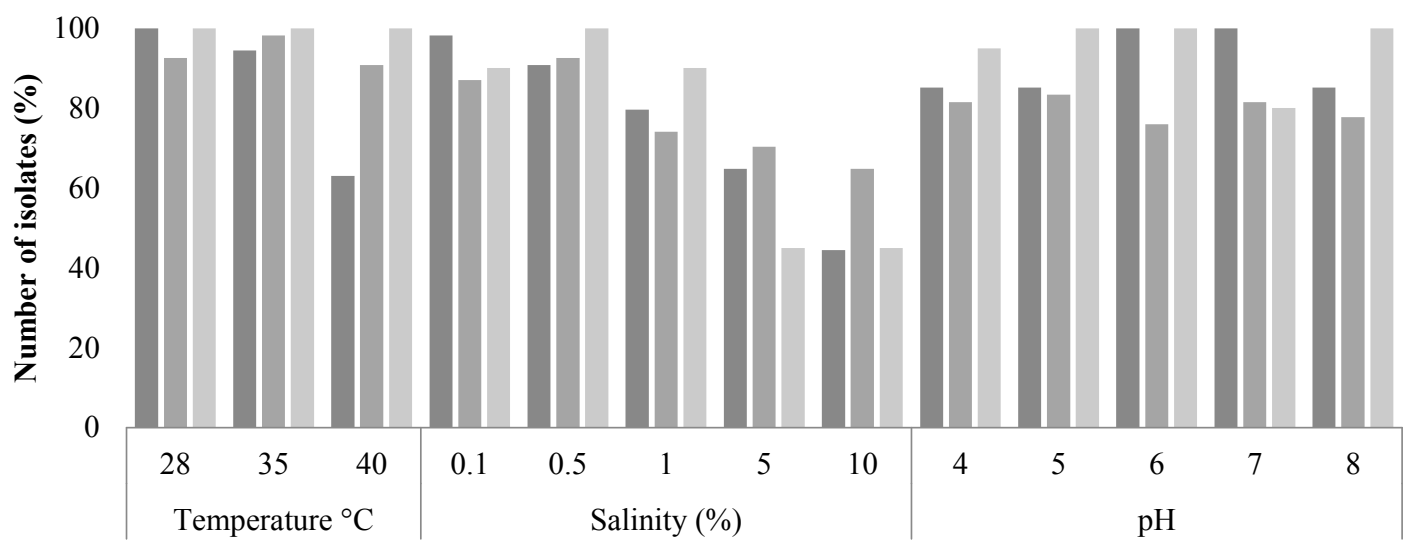

Mimosa tenuiflora $\quad$ Macroptilium atropurpureum $\quad$ Desmanthus pernambucanus

C

São Bento do Una

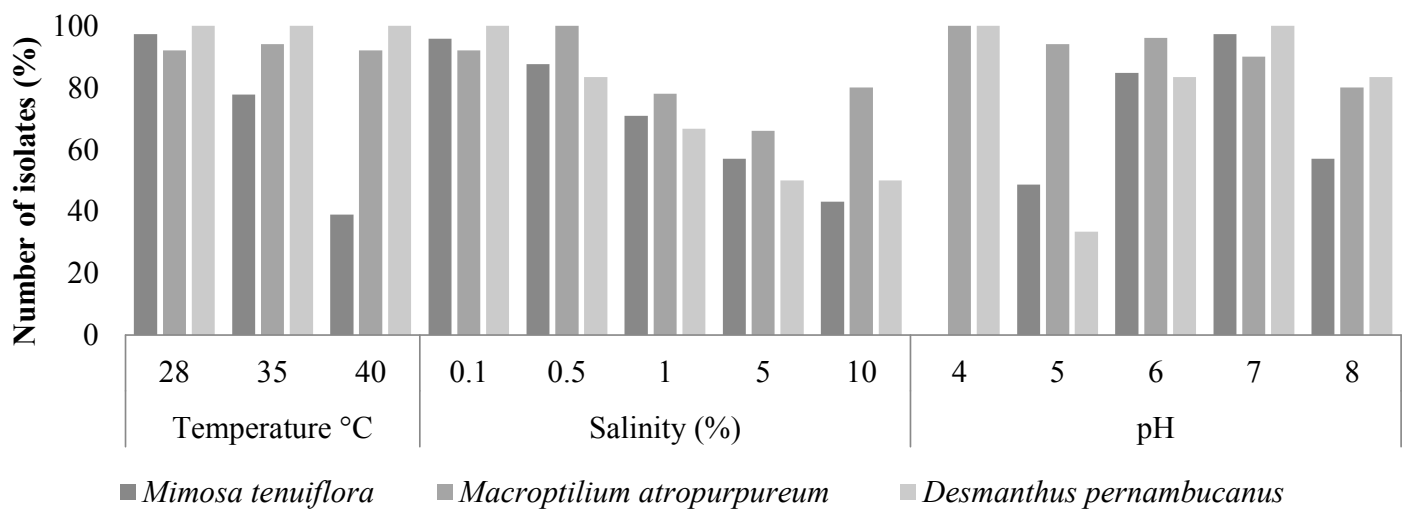

Figure 2. Physiological characteristics of rhizobia isolates in Yeast Mannitol (YM) medium, Mimosa tenuiflora, Macroptilium atropurpureum, and Desmanthus pernambucanus in (A) Sertânia, (B) Arcoverde, and (C) São Bento do Una, Pernambuco, Brazil.

The isolates of the species $D$. pernambucanus also presented higher resistance when treated to temperatures of 40 and $35^{\circ} \mathrm{C}$, regardless of the place of cultivation. The optimal temperature for rhizobia growth varies between species and can range from 27 to $35^{\circ} \mathrm{C}$. Maximum temperatures are usually between 35 and $39^{\circ} \mathrm{C}$, but proliferation can occur up to $42{ }^{\circ} \mathrm{C}$ (NISTE et al., 2013). Some native isolates 
of M. tenuiflora, M. atropurpureum, and D. pernambucanus were able to grow at a temperature of $40{ }^{\circ} \mathrm{C}$, confirming that the temperature limit capable of causing substantial nodule retrogression is a particular bacterial property and is still related to the different Fabaceae species with which they can be associated (ALEXANDRE; OLIVEIRA, 2013).

\section{CONCLUSION}

The morphological characteristics are intrinsic to the microorganisms and not to the evaluated Fabaceae species. The physiological characteristics of rhizobia are influenced by soil type and the symbiotic botanical species. The species Desmanthus pernambucanus has higher nodulation specificity than Mimosa tenuiflora and Macroptilium atropurpureum. The native rhizobia of the semiarid region have resistance to stress caused by high temperatures, salinity increase, and $\mathrm{pH}$.

\section{REFERENCES}

ABD-ALLA, M. H. et al. Alleviating the inhibitory effect of salinity stress on nod gene expression in Rhizobium tibeticum - fenugreek (Trigonella foenum graecum) symbiosis by isoflavonoids treatment. Journal of Plant Interactions, v. 9, n. 1, p. 275$284,2014$.

ALEXANDRE A.; OLIVEIRA S. Response to temperature stress in rhizobia. Critical Reviews in Microbiology, v. 39, n. 3, p. 219-228, 2013.

ARAUJO, K. D. et al. Uso de espécies da caatinga na alimentação de rebanhos no município de São João do Cariri - PB. Revistas Técnico-Científicas da UFPR, v. 20, n. 2, p. 157-171, 2010.

BAKKE I. A. et al. Water and sodium chloride effects on mimosa tenuiflora (willd.) poiret seed germination. Revista Caatinga, v. 19, n. 3, p. 261267, 2006.

BHATTACHARYA， C.; DESHPANDE, B.; PANDEY, B. Isolation and Characterization of Rhizobium sp. form Root of Legume plant (Pisum sativum) and Its Antibacterial Activity against Different Bacterial strains. International Journal of Agricultural and Food Science, v. 3, n. 4, p. 138141, 2013.

CARVALHO, G. G. P.; PIRES, A. J. V. Leguminosas tropicais herbáceas em associação com pastagens. Archivos de Zootecnia, v. 57, n. 1, p. 103-113, 2008.
DAKORA, F. D. Root-nodule bacteria isolated from native Amphithalea ericifolia and four indigenous Aspalathus species from the acidic soils of the South African fynbos are tolerant to very low $\mathrm{pH}$. African Journal of Biotechnology, v. 11, n. 16, p. 37663772, 2012.

DENG, J. et al. Synergistic effects of soil microstructure and bacterial EPS on drying rate in emulated soil micromodels. Soil Biology e Biochemistry. v. 83, n. 4, p. 116-124, 2015.

DUTTA, S. et al. Induction of systemic resistance against fusarial wilt in pigeon pea through interaction of plant growth promoting rhizobacteria and rhizobia. Soil Biology and Biochemistry, v. 40, n. 2, p. 452-461, 2008.

FRED, E. B.; WAKSMAN, S. A. Yeast extractmannitol agar for laboratory manual of general microbiology. New York: McGraw, 1928. 145 p.

FREITAS, A. D. S. et al. Caracterização de rizóbios isolados de jacatupé cultivado em solo salino do estado de Pernambuco, Brasil. Bragantia, v. 66, n. 3, p. 497-504, 2007.

GOMES, D. F.; et al. Proteomic profiling of Rhizobium tropici PRF 81: identification of conserved and specific responses to heat stress. BMC Microbiology, v. 12, n. 1, p. 1-12, 2012.

HUNGRIA, M.; ARAÚJO R.S. Manual de métodos empregados em estudo de microbiologia agrícola. Brasília, DF: Embrapa-Serviço de Produção e Informação, 1994. 519 p.

HUSSAIN, M. B. et al. Can Catalase and Exopolysaccharides Producing Rhizobia Ameliorate Drought Stress in Wheat? International Journal of Agriculture e Biology, v. 16, n. 1, p. 3-13, 2014.

LARANJO, M.; ALEXANDRE, A.; OLIVEIRA, S.; Genes commonly involved in acid tolerance are not overexpressed in the plant microsymbiont Mesorhizobium loti MAFF303099 upon acidic shock. Applied Microbiology and Biotechnology, v. 98, n. 16, p. 7137-7147, 2014.

LARANJO, M.; OLIVEIRA, S. Tolerance of Mesorhizobium type strains to different environmental stresses. Antonie Van Leeuwenhoek, v. 99, n. 3, p. 651-662, 2011.

LEBRAZI, S. F.; BENBRAHIM, K. Environmental stress conditions affecting the N2 fixing Rhizobiumlegume symbiosis and adaptation mechanisms. African Journal of Microbiology Research, v. 8, n. 3, p. 4053-4061, 2014. 
MEDEIROS, E. V. et al. Diversidade morfológica de rizóbios isolados de caupi cultivado em solos do Estado do Rio Grande do Norte. Acta Scientiarum. Agronomy, v. 31, n. 3, p. 529-535. 2009.

MELLONI, R. et al. Eficiência e diversidade fenotípica de bactérias diazotróficas que nodulam caupi (Vigna unguiculata (L.) Walp) e feijoeiro (Phaseolus vulgaris L.) em solos de mineração de bauxita em reabilitação. Revista Brasileira de Ciência do Solo, v. 30, n. 2, p. 235-246, 2006.

MONTEIRO, N. K. et al. Caracterização química dos géis produzidos pelas bactérias diazotróficas rhizobium tropici e mesorhizobium sp. Química Nova, v. 35, n. 4, p. 705-708, 2012.

MOREIRA, F. M. D. S. et al. Bactérias diazotróficas associativas: diversidade, ecologia e potencial de aplicações. Comunicata Scientiae, v. 1, n. 2, p. 7499, 2010.

NISTE, M. et al. Stress Factors Affecting Symbiosis Activity and Nitrogen Fixation by Rhizobium Cultured in vitro. ProEnvironment, v. 6, n. 13, p. 42 $-45,2013$.

OLIVEIRA, C. S. et al. Exopolysaccharides and abiotic stress tolerance in Bacterial isolates from "sabiá" nodules. Revista Caatinga, v. 27, n. 4, p. 240-245, 2014.

SANTOS, C. E. R. S. et al. Diversidade de rizóbios capazes de nodular leguminosas tropicais. Revista Brasileira de Ciências Agrárias, v. 2, n. 4, p. 249256, 2007.

SANTOS, M. J. C.; SANTOS, F. R. Leguminosas arbustivas-arbóreas em sistema silvipastoril no Semiárido sergipano para alimentação de ovinos. Agropecuária Científica no Semiárido, v. 7, n. 3, p. 25-30, 2011.

SILVA, M. V. T. et al. Evolução da salinidade do solo em função de diferentes doses de nitrogênio e salinidade da água de irrigação. Agropecuária Científica no Semiárido, v. 9, n. 2, p. 126-136, 2013.

SOUTO, P. C. et al. Comunidade microbiana e mesofauna edáficas em solo sob Caatinga no Semiárido da Paraíba. Revista Brasileira de Ciências do Solo, v. 32, n. 1, p. 51-160, 2008.

TEIXEIRA, F. C. P. et al. Characterization of indigenous rhizobia from caatinga. Brazilian Journal of Microbiology, v. 41, n. 1, p. 201-208, 2010 .
VINCENT, J. M.; A Manual for the Practical Study of Root Nodule Bacteria. Oxford, Blackwell Scientific Publications, 1970. 164 p.

VORSTER, B. J. et al. The Cysteine ProteaseCysteine Protease Inhibitor System Explored in Soybean Nodule Development. Agronomy, v. 3, n. 3 , p. 550-570, 2013.

VRIEZEN, J. A. C.; BRUIJN, F. J.; NUSSLEIN, K Responses of Rhizobia to Desiccation in Relation to Osmotic Stress, Oxygen, and Temperature. Applied and Environmental Microbiology, v. 73, n. 11, p. 3451-3459, 2007.

YANNI, Y. G.; DAZZO, F. B. Enhancement of rice production using endophytic strains of Rhizobium leguminosarum bv. trifolii in extensive field inoculation trials within the Egypt Nile Delta. Plant and Soil, v. 336, n. 1-2, p. 129-142, 2010. 